\title{
Foliar Epidermal and Pollen Characters of Some Species in the Genus Microcos Linn. in Nigeria
}

\author{
Emmanuel Oyeniyi Shokefun ${ }^{1 *}$, Emobosa Akpo Orijemie², Abiodun Emmanuel Ayodele1 \\ ${ }^{1}$ Department of Botany, University of Ibadan, Ibadan, Nigeria \\ ${ }^{2}$ Department of Archeology and Anthropology, University of Ibadan, Ibadan, Nigeria \\ Email: eo.shokefun@ui.edu.ng, imoresearch@yahoo.com
}

Received 16 October 2014; revised 28 November 2014; accepted 13 December 2014

Copyright (C) 2014 by authors and Scientific Research Publishing Inc.

This work is licensed under the Creative Commons Attribution International License (CC BY). http://creativecommons.org/licenses/by/4.0/

(c) $\underset{\mathrm{EY}}{\mathrm{Br}}$ Open Access

\begin{abstract}
Microcos Linn. (Malvaceae $s . I$ ) is a genus made up of about 60 spp. distributed in Asia and Tropical Africa. In West Africa, 8 species have been recorded of which six species have been documented for Nigeria to occur in lowland rainforest. This study is designed to carry out preliminary foliar epidermal and pollen morphological studies with a view to advance the understanding of the taxonomic relationship between and among species in the genus using the Nigerian taxa. The foliar epidermal and pollen characters were investigated by light microscopy. The epidermises are composed of isodiametric, polygonal or irregular cells. Anticlinal walls are straight, curved or undulate. All taxa are hypostomatic with anisocytic, paracytic and staurocytic stomata types. The mean stomatal size varies from $13.8 \times 13.5 \mu \mathrm{m}$ in M. barombiensis to $16.0 \times 18.0 \mu \mathrm{m}$ in M. coriacea. The dense distribution of stellate trichomes on the abaxial surface of $M$. malacocarpa and the absence of crystals in M. oligoneura are diagnostic for these taxa. The pollen grains are small in size (10 - $25 \mu \mathrm{m}$ ), tricolporate with short colpi, subprolate or prolate. Mean colpi length varies from $15.7 \mu \mathrm{m}$ in $M$. iodocarpa to $17.5 \mu \mathrm{m}$ in M. malacocarpa. The ora size varies from $5.4 \mu \mathrm{m}$ in $M$. barombiensis to $12.5 \mu \mathrm{m}$ in $M$. malacocarpa. The ambient and ora size are significant in the delimitation of the studied taxa. The two groups obtained from epidermal and pollen characters correlate with those earlier obtained from morphological data.
\end{abstract}

\section{Keywords}

Leaf Epidermis, Pollen, Microcos, Nigeria, Taxonomy

\footnotetext{
"Corresponding author.
}

How to cite this paper: Shokefun, E.O., Orijemie, E.A. and Ayodele, A.E. (2014) Foliar Epidermal and Pollen Characters of Some Species in the Genus Microcos Linn. in Nigeria. American Journal of Plant Sciences, 5, 3904-3913. 


\section{Introduction}

Microcos Linn. is a genus of woody climbers and small trees characterized by undivided leaves. The leaf is not always recognized as Malvaceous because of the short and apparently unswollen leaf stalk. The flowers are small, numerous and hermaphroditic with growing panicles composed of large numbers of three flower cymes [1] [2]. The genus is made up of about 60 to 80 species in the Indo-Malaysia and Africa [3]-[6]. In Tropical Africa, about 18 species are known of which 6 species occur in Nigeria [6] and [7]. Among the Nigerian species, only Microcos coriacea is a tree, while the other species are shrubs and woody climbers. Microcos coriacea and M. malacocarpa are the most abundant of the Nigerian taxa. Recently, [1] [3] [8]-[10] and [2] reported that based on the morphological, leaf epidermal, pollen morphological, wood anatomical characters and plastid atpB and $r b c \mathrm{~L}$ DNA sequences, Microcos and Grewia should be treated as two distinct genera. Reference [6] suggested the need for a critical revision of the taxonomy of the genus to reflect the present state of its knowledge since the last revision of the group in Africa was reported by [11]. In the Nigerian flora (Flora of West Tropical Africa), species of the genus Microcos were lumped together as a section in the genus Grewia Lin. [7]. However, they were distinguished by their panicle inflorescence and small flower size from the cymose species of Grewia [7].

The taxonomic importance of pollen and leaf anatomical characters is well documented in botanical literature [12]-[14]. Nevertheless, Taxonomists depend to a large extent on morphological characters both for classification and diagnostic purposes. The morphological and anatomical characters of leaves are the most widely considered of all the non-reproductive organ characters. The increased attention paid to them now is primarily aimed at investigating whether their micro characters are more conservative and better taxonomic indicators than the macro characters [15]. The value of pollen morphology in the delimitation and classification of plants has been studied by several workers who have used it in their taxonomic treatments at different levels [16]. Though, recent studies of the temperate species of the genus Microcos have yielded useful data concerning intra and inter specific variation patterns as well as geographical relationship of some taxa [5], the dearth of knowledge on the tropical taxa has made identification difficult and contributed to the lack of understanding of the intricate pattern of variation within and among the species in the genus. However, an attempt is made at advancing the understanding of the taxonomic relationship between and among species in the genus using the Nigerian taxa. The present study therefore aimed at carrying out a preliminary foliar epidermal and pollen morphological studies on the six Nigeria species vis: M. africana (HooK.f.) Burret., Microcos barombiensis K. Schum, M. coriacea (Mast.) Burret., M. iodocarpa Burret., M. malacocarpa (Mast.) Burret. and M. oligoneura (Sprague) Burret. with a view to broadening the scope of knowledge of this genus in this part of the world.

\section{Materials and Methods}

\subsection{Source of Plant Materials}

The foliar and pollen materials of the six species were procured from dried herbarium specimens from the Forestry Herbarium Ibadan (FHI) and University of Ibadan Herbarium (UIH). Table 1 gives the list of specimens studied.

\subsection{Micromorphology}

\section{Preparation of Epidermal Peel}

The dried herbarium leaf specimens were first rehydrated by soaking in boiling or boiled water for about 20 minutes before use. Leaves of the specimens cut at the median portions were soaked in concentrated Trioxonitrate (VI) acid for about 8 hrs depending on the texture of the leaves according to the procedure described by [17]. The appearance of air bubbles indicated the readiness of the epidermises to be separated. The samples were then transferred to Petri dishes containing water and with the use of fine forceps and dissecting needle the upper and lower epidermises were separated [18]. These were cleared with camel hair brush in water to remove residual mesophyll layers. The peels were stained with toluidine for 3 to 5 minutes, rinsed in water and mounted in glycerol on clean glass slide. The slides were observed and studied using the light microscope. Photomicrographs were taken using Leica CME with Digital Microscope Eyepiece attachment and Photo Explorer 8.0 SE basic software. 
Table 1. List of Microcos specimens studied.

\begin{tabular}{|c|c|c|c|c|c|}
\hline $\mathbf{S} / \mathbf{n}$ & Taxa & Locality & Names of collectors & $\begin{array}{l}\text { Voucher } \\
\text { numbers }\end{array}$ & Date \\
\hline 1. & M. barombiensis & $\begin{array}{l}\text { Cross river, Nigeria } \\
\text { Abeokuta, Ogun, Nigeria } \\
\text { Ilaro, Ogun, Nigeria } \\
\text { Ikom, Edo, Nigeria } \\
\text { Ondo, Nigeria }\end{array}$ & $\begin{array}{l}\text { Emwiogbon \& Osanyinlusi } \\
\text { P. Wit \& B. O. Daramola } \\
\text { P. P. C. Van Meer } \\
\text { J. C. Okafor \& M. G. Latilo } \\
\text { C. F. A. Onochie }\end{array}$ & $\begin{array}{c}\text { FHI } 86982 \\
64882 \\
22220 \\
57257 \\
33418\end{array}$ & $\begin{array}{c}4-10-77 \\
28-12-71 \\
14-8-68 \\
21-9-65 \\
29-7-73\end{array}$ \\
\hline 2. & M. iodocarpa & $\begin{array}{l}\text { Ondo, Nigeria } \\
\text { Oyo, Nigeria } \\
\text { Lagos, Nigeria } \\
\text { Ondo, Nigeria }\end{array}$ & $\begin{array}{c}\text { A. P. D. Jones } \\
\text { R. W. J. Keay \& A. P. D. Jones } \\
\text { A. H. Batten Poole } \\
\text { Oyeachusim, Onijamowo \& Ibhanesebhor }\end{array}$ & $\begin{array}{c}\text { FHI } 3591 \\
42020 \\
13296\end{array}$ & $\begin{array}{c}9-5-43 \\
4-11-45 \\
1946\end{array}$ \\
\hline 3. & M. coriacea & $\begin{array}{l}\text { Portharcort, Nigeria } \\
\text { Delta, Nigeria } \\
\text { Ondo, Nigeria } \\
\text { Benin, Nigeria } \\
\text { Ogun, Nigeria } \\
\text { J4, Ogun, Nigeria }\end{array}$ & $\begin{array}{l}\text { J. A. Emwiogbon } \\
\text { J. A. Emwiogbon } \\
\text { J. A. Emwiogbon } \\
\text { J. Lowe } \\
\text { J. Lowe } \\
\text { Shokefun \& Odewo }\end{array}$ & $\begin{array}{c}\text { FHI } 60333 \\
89348 \\
56805 \\
\text { UIH } 21623 \\
20583 \\
\text { SEO } 012\end{array}$ & $\begin{array}{c}12-8-66 \\
8-11-76 \\
26-7-65 \\
8-3-91 \\
17-12-84 \\
10-06-09\end{array}$ \\
\hline 4. & M. africana & Ijebu, Ogun, Nigeria & C. Onochie \& Others & FHI 20675 & $26-1-47$ \\
\hline 5. & M. malacocarpa & $\begin{array}{l}\text { Owo, Ondo, Nigeria } \\
\text { Abeokuta, Ogun, Nigeria } \\
\text { Iwo, Osun, Nigeria } \\
\text { Ishan, Edo, Nigeria } \\
\text { Calabar, Nigeria } \\
\text { Ibadan, Oyo, Nigeria } \\
\text { Enugu, Nigeria } \\
\text { Delta, Nigeria }\end{array}$ & $\begin{array}{c}\text { J. P. D. Jones } \\
\text { P. Wit \& C. Geerling } \\
\text { J. K. Adebusuyi } \\
\text { Ibhanesebhor, Odewo \& Oguntayo } \\
\text { Edwin Ujor } \\
\text { ILae Elderry } \\
\text { J. A. Emwiogbon } \\
\text { J. A. Emwiogbon }\end{array}$ & $\begin{array}{c}\text { FHI } 3465 \\
64989 \\
18239 \\
91141 \\
31643 \\
8202 \\
60363 \\
61108\end{array}$ & $\begin{array}{c}17-4-43 \\
11-3-72 \\
15-4-59 \\
19-5-79 \\
18-7-52 \\
4-1-45 \\
4-8-66 \\
20-3-68\end{array}$ \\
\hline 6. & M. oligoneura & Ikom, Edo, Nigeria & A. P. D. Jones \& C. F. Onochie & FHI 5806 & $14-5-46$ \\
\hline
\end{tabular}

Twenty five measurements of each of the characters were taken at random using a micrometer eyepiece graticule and the mean and standard error calculated. Terminologies are based on [13] [19] and [20].

The Stomata Index (SI) was calculated using the formula of [21].

$$
\mathrm{SI}=\frac{\mathrm{S}}{\mathrm{S}+\mathrm{EX}} \times 100 \%
$$

where $\mathrm{S}=$ No. of stomata per unit area; $\mathrm{E}=$ No. of epidermal cells in the same unit area.

\subsection{Pollen Morphology}

The dried flower and floral buds from herbarium specimens were assessed for pollen morphology using acetolysis method according to the procedures described by [22] [23] and modified by [24]. The floral buds were crushed with a glass rod in centrifuge tube. Three milliliter of freshly prepared acetolysis mixture (9 parts acetic anhydride to 1 part concentrated Tetraoxosulphate VI acid) was added to the content in the tubes. The content was heated in a water bath from $70^{\circ} \mathrm{C}$ to boiling point and stirred occasionally. The centrifuge tubes and content were left in boiling water for 3 minutes and then centrifuged at 4000 r.p.m. for 5 minutes while still hot. The supernatant was decanted into acetolysis waste bottle before the addition of some water to the sediments in the tubes, and was shaken vigorously using a whirl mixer. Few drops of methylated spirit were added to remove the foam formed and centrifuged again. The supernatant was decanted, washed with water, and centrifuged repeatedly four times. Fifty percent glycerin was added and left standing for two hours. The tubes were shaken vigorously using a whirl mixer and centrifuged at 4000 r.p.m. for 10 minutes. The supernatant was finally decanted off, and the tube was inverted over filter paper and left overnight. One hundred percent glycerol was added to the tubes, shaken and poured into labeled storage vials. The pollen grains were mounted in unstained glycerin jelly. The slides were examined with a Fisher scientific illumination microscope under (E 40; 0.65), oil immersion (E 100; 1.25) using 10× eye piece. The measurement was based on 20 readings from each specimen. Photomicrographs were taken using Leica CME with Digital Microscope Eyepiece attachment and Photo Explorer 
8.0 SE basic software. Terminologies were based on [22] [25] and [26].

\section{Results}

\subsection{Micro Morphological Characters}

The epidermal cells were isodiametric to polygonal on both surfaces in M. oligoneura and the adaxial surface in M. malacocarpa (Plate $1 \mathrm{i}, \mathrm{k}$ and l). Anticlinal wall pattern may be straight to curve (M. oligoneura) or wavy to undulate in the other taxa (Table 2). The leaves are hypostomatic with staurocytic, paracytic and anisocytic stomata in all the species. Crystal was absent in $M$. coriacea and M. oligoneura (Table 2). The number of epidermal cells $/ \mathrm{mm}^{2}$ on the leaf adaxial surface was lowest in M. malacocarpa (184) and highest in M. oligoneura (761) on the adaxial surface. It was lowest in M. barombiensis and M. africana (189) but highest in M. coriacea (218) on the abaxial surfaces. The number of epidermal cells on the abaxial surface in M. malacocarpa could not be ascertained due to dense distribution of trichomes on the surface. The adaxial and abaxial epidermal cell widths were of the same size in M. africana and M. oligoneura while the rest of the species had wider epidermal cells on the adaxial surface. The largest cell width of $20.3 \mu \mathrm{m}$ was recorded on the adaxial surface in $M$. iodocarpa and $16.3 \mu \mathrm{m}$ on the abaxial surface in M. africana while the lowest cell width of $13.1 \mu \mathrm{m}$ and $12.5 \mu \mathrm{m}$ were recorded on both adaxial and abaxial surfaces in M. oligoneura. The highest number of stomata of 135 was recorded on the abaxial surface in $M$. oligoneura while the lowest of 70 was recorded in $M$. barombiensis (Table 3). The largest stomata size of $16 \times 18.0 \mu \mathrm{m}$ was recorded in $M$. coriacea, while the smallest of $13.8 \times$ $14.0 \mu \mathrm{m}$ was recorded in M. barombiensis (Table 3). Stomatal index was highest (41.1\%) in M. oligoneura and lowest (27.1\%) in M. barombiensis. Cell wall thickness ranged from 2.5 - 5.0 on adaxial and 2.5 to 4.0 on the abaxial surface in the genus. Trichomes were glandular and non glandular in most taxa. However, only simple and glandular trichomes were recorded in M. oligoneura. Trichome bases were observed in most taxa but absent on the abaxial surface in M. coriacea and on both surfaces in M. africana (Table 2). Crystals were absent in M. coriacea and M. oligoneura (Table 2), but druses, prismatic and styloid crystals were recorded in other taxa.

\subsection{Pollen Morphological Characters}

The pollen grains of Microcos species studied were isopolar and radially symmetrical with polar axis ranging between 19.7 - $24.4 \mu \mathrm{m}$, the equatorial diameter 14.7 - $17.4 \mu \mathrm{m}$ and the P/E ratio 125\% - 142\%. The pollen class
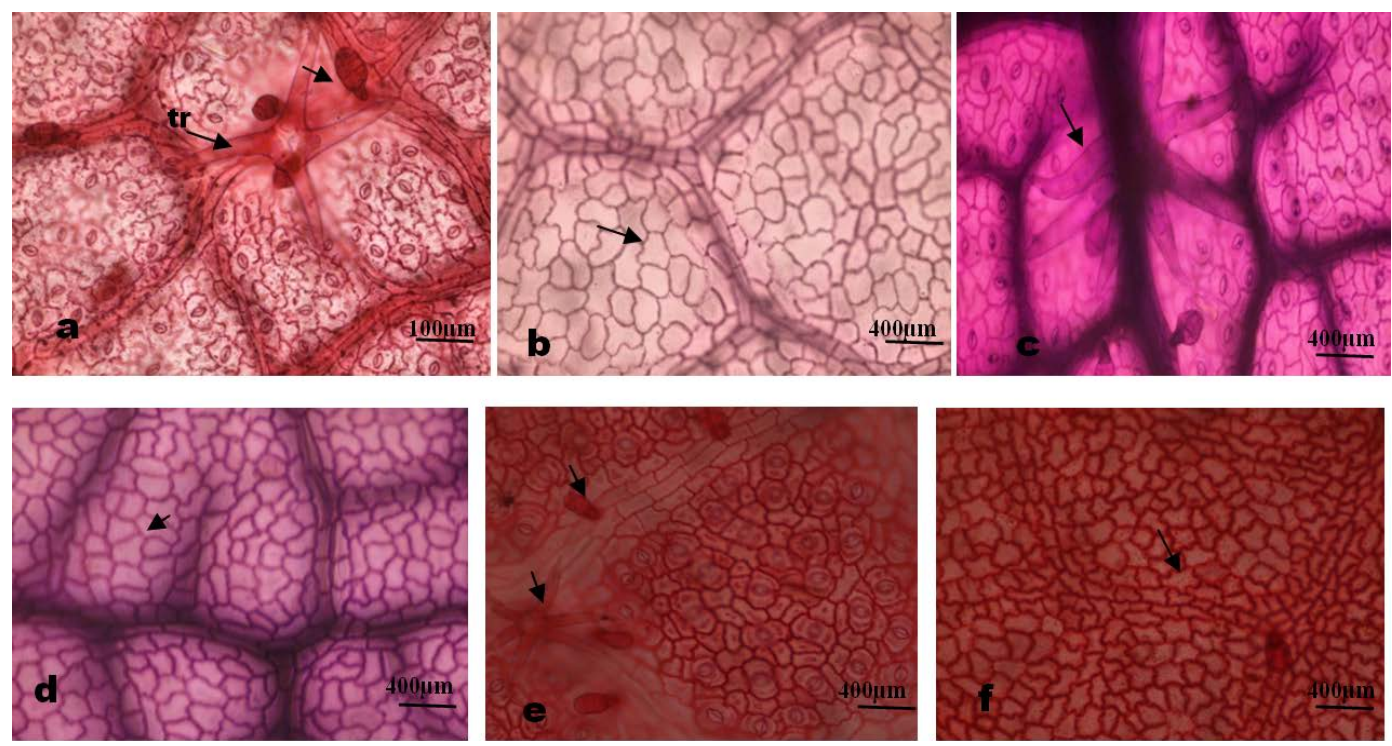

Plate 1. Photomicrographs of leaf epidermal features of Microcos species. (a) M. barombiensis, abaxial surface showing 4 armed and 3 celled uniseriate glandular trichomes on veins; (b) Adaxial showing wavy anticlinal cell wall; (c) M. iodocarpa, abaxial surface showing stellate trichome on veins; (d) Adaxial showing wavy anticlinal walls; (e) M. coriacea, abaxial surface showing anisocytic, staurocytic and paracytic stomata and multicellular glandular and stellate trichomes on veins; (f) Showing relatively thick undulate anticlinal wall. 
Table 2. Qualitative leaf epidermal characters of the genus Microcos in Nigeria.

\begin{tabular}{|c|c|c|c|c|c|c|c|c|c|c|}
\hline \multirow[t]{2}{*}{$\mathbf{S} / \mathbf{n}$} & \multirow[t]{2}{*}{ Taxa } & \multicolumn{2}{|c|}{ Cell shape } & \multicolumn{2}{|c|}{$\begin{array}{c}\text { Anticlinal } \\
\text { wall pattern }\end{array}$} & \multicolumn{2}{|c|}{ Type of stomata } & \multicolumn{2}{|c|}{ Type of trichome } & \multirow[t]{2}{*}{ Crystal } \\
\hline & & Adaxial & Abaxial & Adaxial & Abaxial & Adaxial & Abaxial & Adaxial & Abaxial & \\
\hline 1. & M. barombiensis & Irregular & Irregular & Wavy & Undulate & Absent & $\begin{array}{l}\text { Para, Ani, } \\
\text { Stau }\end{array}$ & 4 celled mct, S & $\begin{array}{l}\text { S, } 2 \text { - } 4 \text { armed, Ss, } \\
3 \text { celled ust }\end{array}$ & $\begin{array}{l}\text { Styloid, } \\
\text { druses }\end{array}$ \\
\hline 2. & M. iodocarpa & Irregular & Irregular & Wavy & Undulate & Absent & $\begin{array}{l}\text { Para, Ani, } \\
\quad \text { Stau }\end{array}$ & $\begin{array}{l}\text { S \& Ss, } 2 \text { armed, } \\
3 \text { celled ust }\end{array}$ & $\begin{array}{l}, 2 \text { - } 4 \text { armed, Ss, S \& } \\
3 \text { - } 4 \text { celled ust \& mct }\end{array}$ & Druses \\
\hline 3. & M. coriacea & Irregular & Irregular & Wavy & Undulate & Absent & $\begin{array}{l}\text { Para, Ani, } \\
\text { Stau }\end{array}$ & 3 - 4 celled mct & $\begin{array}{l}3 \text { - } 4 \text { armed, Ss, } 4 \text { - } \\
5 \text { celled ust \& mct }\end{array}$ & Absent \\
\hline 4. & M. africana & Irregular & Irregular & Wavy & Undulate & Absent & $\begin{array}{l}\text { Para, Ani, } \\
\text { Stau }\end{array}$ & $\begin{array}{l}\text { Ss, S, } 3 \text { - } 4 \text { celled } \\
\text { ust \& mct }\end{array}$ & $\begin{array}{l}\text { d3 - } 4 \text { armed, Ss, S, } 3 \\
\text { celled ust }\end{array}$ & $\begin{array}{c}\text { Prismatic, } \\
\text { styloid, druses }\end{array}$ \\
\hline 5. & M. malacocarpa & $\begin{array}{l}\text { Isodiametric/ } \\
\text { polygonal }\end{array}$ & Irregular & $\begin{array}{l}\text { Straight/ } \\
\text { curve }\end{array}$ & Undulate & Absent & N.A & $\begin{array}{c}\text { Ss, } 3 \text { - } 4 \text { celled } \\
\text { mct }\end{array}$ & Ss & $\begin{array}{c}\text { Prismatic, } \\
\text { styloid, druses }\end{array}$ \\
\hline 6. & M. oligoneura & Isodiametric & Polygonal & Straight & $\begin{array}{l}\text { Straight/ } \\
\text { curve }\end{array}$ & Absent & $\begin{array}{l}\text { Para, Ani, } \\
\text { Stau }\end{array}$ & S, 3 celled ust & 3 celled mct & Absent \\
\hline
\end{tabular}

Key: Stau = staurocytic stomata, Ani = anisocytic stomata, Para = paracytic stomata, $\mathrm{S}=$ simple trichome, $\mathrm{Ss}=$ stellate trichome, mst $=$ multiseriate glandular trichome, $\mathrm{mct}=$ multicellular glandular trichome, ust $=$ uniseriate glandular trichome, $2-4$ armed $=2-4$ branched non glandular trichomes .

Table 3. Quantitative epidermal and stomata characters of the genus Grewia in Nigeria.

\begin{tabular}{|c|c|c|c|c|c|c|c|c|c|c|c|c|c|c|}
\hline \multirow{3}{*}{$\underset{\text { n }}{\text { S/ Taxa }}$} & \multirow{2}{*}{\multicolumn{2}{|c|}{$\begin{array}{l}\text { Number of } \\
\text { epidermal } \\
\text { cells }\left(\mathrm{mm}^{2}\right)\end{array}$}} & \multirow{2}{*}{\multicolumn{2}{|c|}{$\begin{array}{l}\text { Cell width } \\
\text { ( } \mu \mathrm{m})\end{array}$}} & \multirow{2}{*}{\multicolumn{2}{|c|}{$\begin{array}{c}\text { Cell wall } \\
\text { thickness }(\mu \mathrm{m})\end{array}$}} & \multicolumn{8}{|c|}{ STOMATA } \\
\hline & & & & & & & \multicolumn{2}{|c|}{$\begin{array}{c}\text { Number } \\
\left(\mathrm{mm}^{2}\right)\end{array}$} & \multicolumn{2}{|c|}{$\begin{array}{c}\text { Length } \\
\text { ( } \mu \mathrm{m})\end{array}$} & \multicolumn{2}{|c|}{$\begin{array}{l}\text { width } \\
\text { ( } \mu \mathrm{m})\end{array}$} & \multicolumn{2}{|c|}{$\begin{array}{c}\text { Index } \\
(\%)\end{array}$} \\
\hline & 矛 & 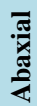 & $\begin{array}{l}\text { 조x } \\
\frac{\pi}{2}\end{array}$ & 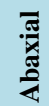 & 荧 & 㸚 & 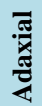 & $\begin{array}{l}\text { ] } \\
\frac{\pi}{x}\end{array}$ & $\begin{array}{l}\frac{\pi}{x} \\
\frac{\pi}{x} \\
\frac{\pi}{2}\end{array}$ & 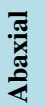 & $\begin{array}{l}\text { 좀 } \\
\frac{\sqrt{x}}{2}\end{array}$ & 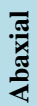 & 芠 & $\begin{array}{l}\frac{\pi}{x} \\
\frac{\pi}{2} \\
\frac{\pi}{2}\end{array}$ \\
\hline
\end{tabular}

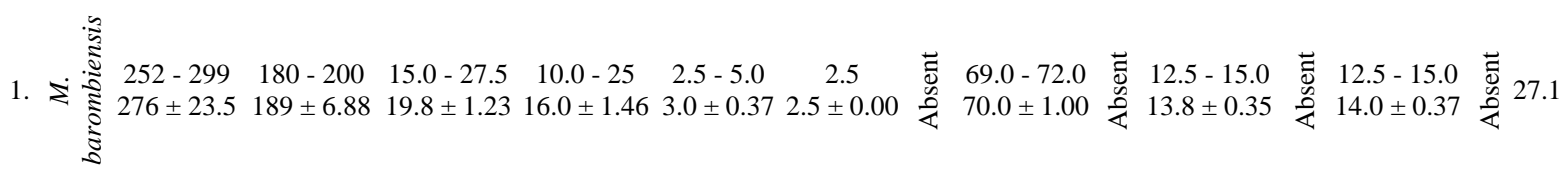

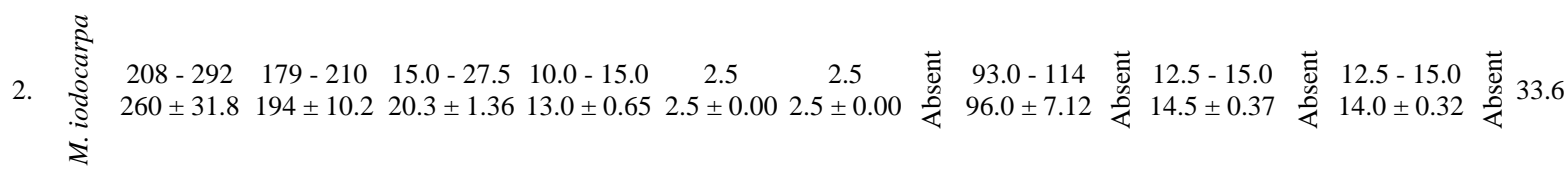

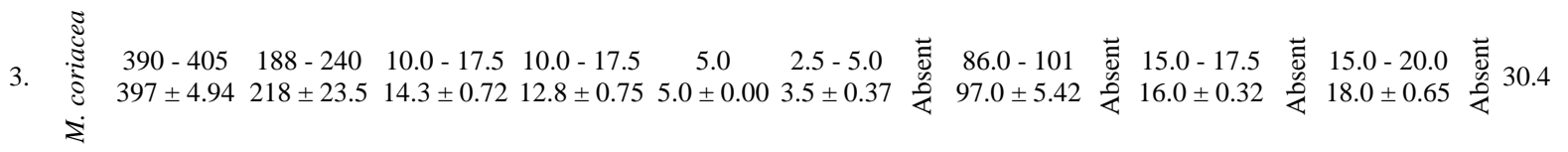

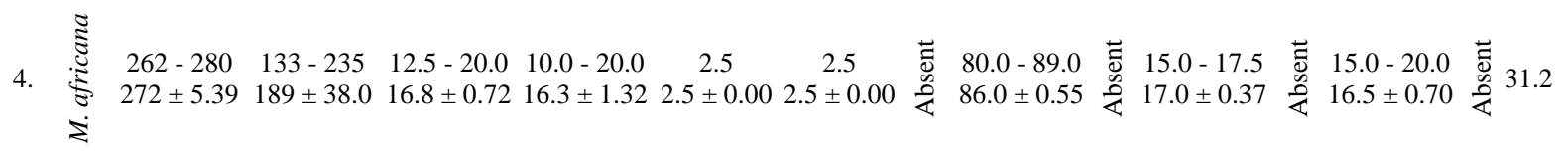

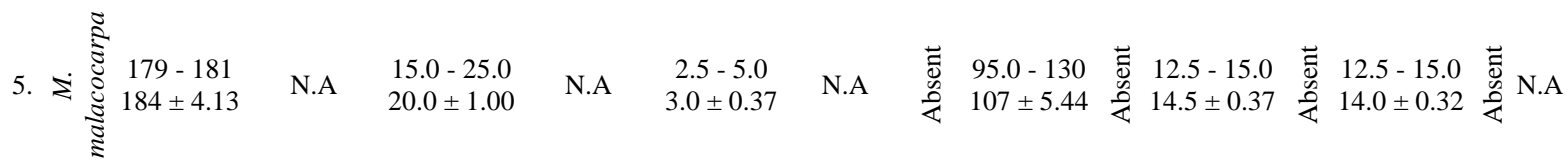

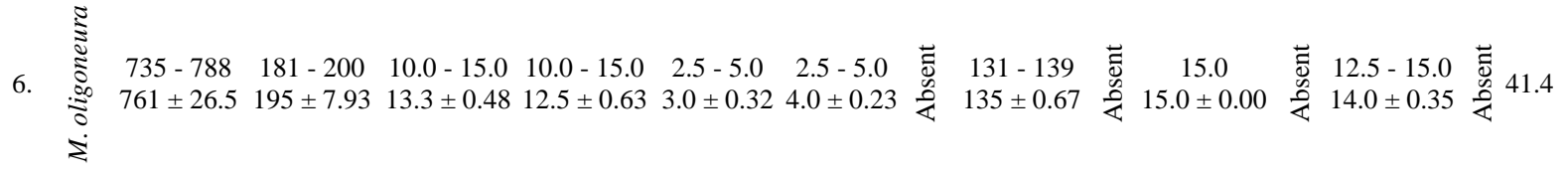


was prolate to subprolate, ambient round to trilobed (M. africana). The pollen grains were tricolporate with narrow, short colpi $15.7 \mu \mathrm{m}$ to $17.7 \mu \mathrm{m}$ long and lalongate ora, $5.4-12.5 \mu \mathrm{m}$ broad. The exine was $0.61-1.32 \mu \mathrm{m}$ thick, sexine thicker than nexine and the exine sculpture was finely reticulate. The muri ridge was entire with round-angular to elongated round lumina shape (Table 4; Plate 2).

Table 4. Qualitative and quantitative pollen morphological characters of Grewia species in Nigeria.

\begin{tabular}{|c|c|c|c|c|c|c|c|c|c|c|c|c|}
\hline Taxa & $\begin{array}{c}\text { Exine } \\
\text { pattern }\end{array}$ & $\begin{array}{c}\text { lumina } \\
\text { shape }\end{array}$ & Amb & $\begin{array}{l}\text { Colpi } \\
\text { ends }\end{array}$ & $\begin{array}{c}\text { Pollen } \\
\text { class }\end{array}$ & $\begin{array}{c}\text { Pollen } \\
\text { size }(\mu \mathrm{m})\end{array}$ & $\begin{array}{c}\text { Polar } \\
\text { axis } \\
(\mu \mathrm{m})\end{array}$ & $\begin{array}{c}\text { Equator } \\
\text { diameter } \\
(\mu \mathrm{m})\end{array}$ & $\begin{array}{c}\text { Exine } \\
(\mu \mathrm{m})\end{array}$ & $\begin{array}{c}\text { Colpus } \\
\text { length } \\
\text { ( } \mu \mathrm{m})\end{array}$ & $\begin{array}{c}\text { Ora } \\
\text { size } \\
(\mu \mathrm{m})\end{array}$ & $\begin{array}{c}\text { PA/ED } \\
\%\end{array}$ \\
\hline $\begin{array}{c}\text { M. } \\
\text { 1. barombiensis }\end{array}$ & Reticulate & $\begin{array}{l}\text { Round- } \\
\text { angular }\end{array}$ & Round & $\begin{array}{c}\text { Acute/ } \\
\text { round/ } \\
\text { open }\end{array}$ & $\begin{array}{c}\text { Sub- } \\
\text { prolate }\end{array}$ & $10-25$ & $\begin{array}{l}21.0-27.5 \\
24.4 \pm 0.59\end{array}$ & $\begin{array}{l}15.0-20.0 \\
17.1 \pm 0.46\end{array}$ & $\begin{array}{l}0.50-0.75 \\
0.61 \pm 0.03\end{array}$ & $\begin{array}{l}15.5-18.2 \\
16.9 \pm 0.28\end{array}$ & 5.4 & 142 \\
\hline 2. M. iodocarpa & Reticulate & $\begin{array}{c}\text { Round } \\
\text { elongated }\end{array}$ & Round & $\begin{array}{l}\text { Acute/ } \\
\text { round }\end{array}$ & Prolate & $10-25$ & $\begin{array}{l}19.2-20.0 \\
19.7 \pm 0.17\end{array}$ & $\begin{array}{l}12.8-17.0 \\
14.8 \pm 0.21\end{array}$ & $\begin{array}{l}0.75-1.25 \\
1.00 \pm 0.01\end{array}$ & $\begin{array}{l}15.0-16.5 \\
115.7 \pm 0.16\end{array}$ & 8.5 & 134 \\
\hline 3. M. coriacea & Reticulate & $\begin{array}{l}\text { Round } \\
\text { elongated }\end{array}$ & Round & $\begin{array}{c}\text { Acute/ } \\
\text { round/ } \\
\text { open }\end{array}$ & Prolate & $10-25$ & $\begin{array}{l}20.0-23.7 \\
21.8 \pm 2.35\end{array}$ & $\begin{array}{l}15.0-17.5 \\
16.2 \pm 1.25\end{array}$ & $\begin{array}{l}1.25-1.50 \\
1.32 \pm 0.04\end{array}$ & $\begin{array}{r}15.7-18.0 \\
16.4 \pm 1.79\end{array}$ & 10.0 & 134 \\
\hline 4. M. africana & Reticulate & $\begin{array}{l}\text { Round- } \\
\text { angular }\end{array}$ & Trilobed & $\begin{array}{l}\text { Acute/ } \\
\text { round }\end{array}$ & Prolate & $10-25$ & $\begin{array}{l}17.5-20.3 \\
19.8 \pm 1.15\end{array}$ & $\begin{array}{l}10.0-15.0 \\
14.7 \pm 0.86\end{array}$ & $\begin{array}{l}1.00-1.25 \\
1.21 \pm 0.06\end{array}$ & $\begin{array}{l}17.5-17.7 \\
17.5 \pm 0.81\end{array}$ & 7.5 & 134 \\
\hline $\begin{array}{c}\text { 5. } \\
\quad \text { malacocarpa }\end{array}$ & Reticulate & $\begin{array}{l}\text { Round- } \\
\text { angular }\end{array}$ & Round & $\begin{array}{c}\text { Acute/ } \\
\text { round/ } \\
\text { open }\end{array}$ & $\begin{array}{c}\text { Sub- } \\
\text { prolate }\end{array}$ & $10-25$ & $\begin{array}{l}18.7-25.0 \\
21.8 \pm 1.11\end{array}$ & $\begin{array}{l}16.2-18.7 \\
17.4 \pm 0.78\end{array}$ & $\begin{array}{c}0.75-1.00 \\
0.86 \pm 0.06\end{array}$ & $\begin{array}{l}17.5-18.0 \\
17.7 \pm 0.72\end{array}$ & 12.5 & 125 \\
\hline 6. M. oligoneura & N.A & N.A & N.A & N.A & N.A & N.A & N.A & N.A & N.A & N.A & N.A & N.A \\
\hline
\end{tabular}

N.A = not available.
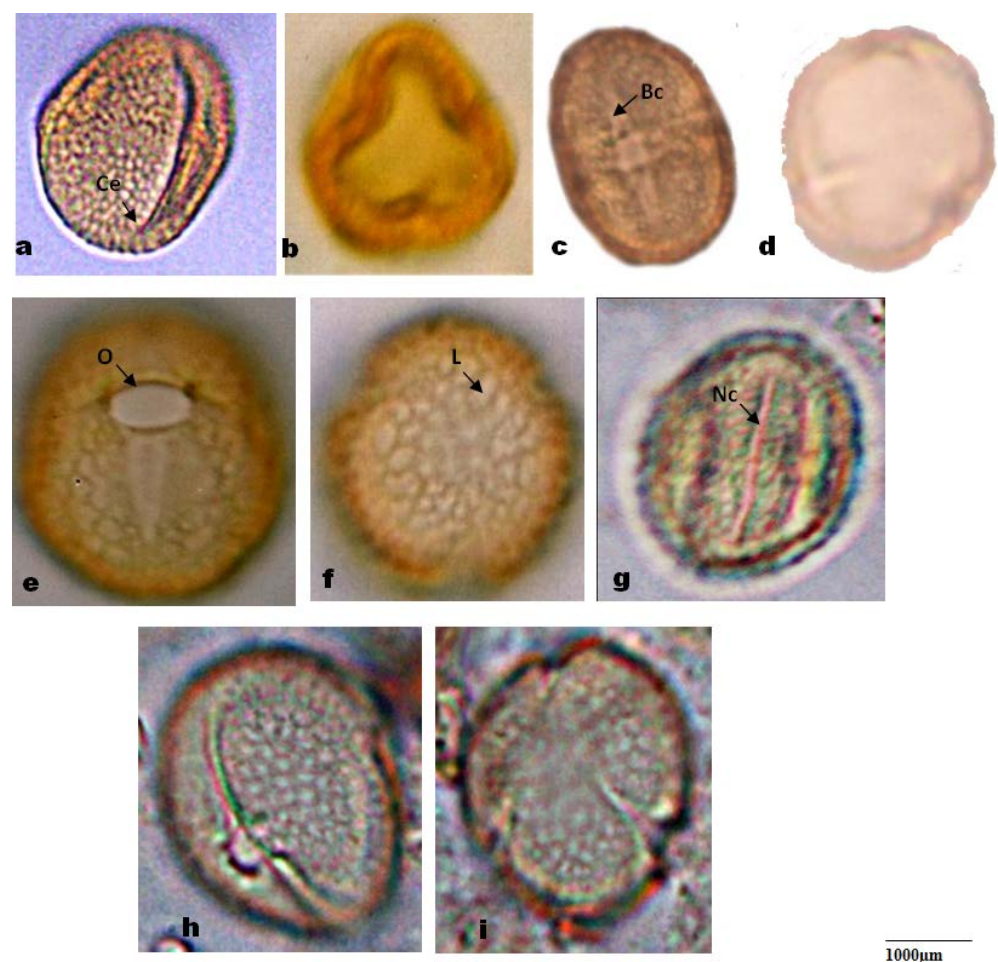

Plate 2. Photomicrographs of pollen grains of Microcos. (a)-(b) M. africana equatorial and polar view showing trilobed Amb; (c)-(d) M. barombiensis equatorial view; (e)-(f) M. coriacea equatorial and polar view; (g) M. iodocarpa equatorial view; (h)-(i) M. malacocarpa equatorial and polar view. Bc: broad colpi, Nc: narrow colpi, Ce: Colpi end, C: colpi, O: Ora, L: lumina. 


\section{Discussion}

The results obtained from this study conform to the classification of the African species of the genus Microcos based on morphological characters by [11] and shows that foliar epidermal and pollen morphological features are useful for identification of the six species of Microcos studied. Two groups are recognized based on the epidermal cell shape, cell wall pattern and number of cells in the glandular trichomes. The first group consists of $M$. barombiensis, $M$. iodocarpa and $M$. africana with irregular epidermal cell shape, undulate walls on both surfaces and 3 to 4 celled head glandular trichomes. The second but diverse group consists of $M$. coriacea, $M$. malacocarpa and $M$. oligoneura which have different combinations of epidermal cell shapes, cell wall pattern, number of stomata, presence and absence of crystals and number of cells in glandular trichomes. Epidermal cells are larger on the adaxial surface than the abaxial surfaces in most taxa but of the same size in M. africana and M. oligoneura. Reference [27] was of the opinion that adaxial epidermal cells are larger than abaxial epidermal cells and can be diagnostic in some groups. The hypostomatic nature of all studied species is probably an adaptation to water as it is expected to confer an ecological advantage on them to survive as perennial plants [28]. Reference [20] and [29], reported tetracytic and anomocytic stomata types for Microcos in the family Tiliaceae. In the present study anisocytic, paracytic and staurocytic stomata types were encountered in all the species studied with anisocytic stomata being the most predominant. This is an unexpected deviation which may be related to species studied by them. The importance of stomatal complex especially in the identification of small leaf fragments has been noted by [13] and [30]. The relative abundance and variation of the trichomes is of taxonomic importance in the species studied. Reference [20] noted that trichome frequency and sizes are environmentally controlled while [13] opined that hairs are constant in a species when present and showed a constant range of form and distribution useful in diagnosis. Dense distribution of stellate trichomes on the abaxial surface of M. malacocarpa distinguished it from other taxa with sparse distribution of trichomes on the abaxial surfaces (Plate 3(c)). The presence of 4 to 5 celled head glandular trichomes in $M$. coriacea and presence of only 3 celled head glandular trichomes in M. oligoneura are diagnostic for the species (Table 1). Absence of crystals in the epidermal cells of $M$. coriacea and M. oligoneura is also diagnostic for them.

Palynological evidence shows that the genus Microcos is stenopalynous with subprolate to prolate, small tricolporate grains. However, [26] considered medium and tricolporate grains to be basic pollen type in the genus.
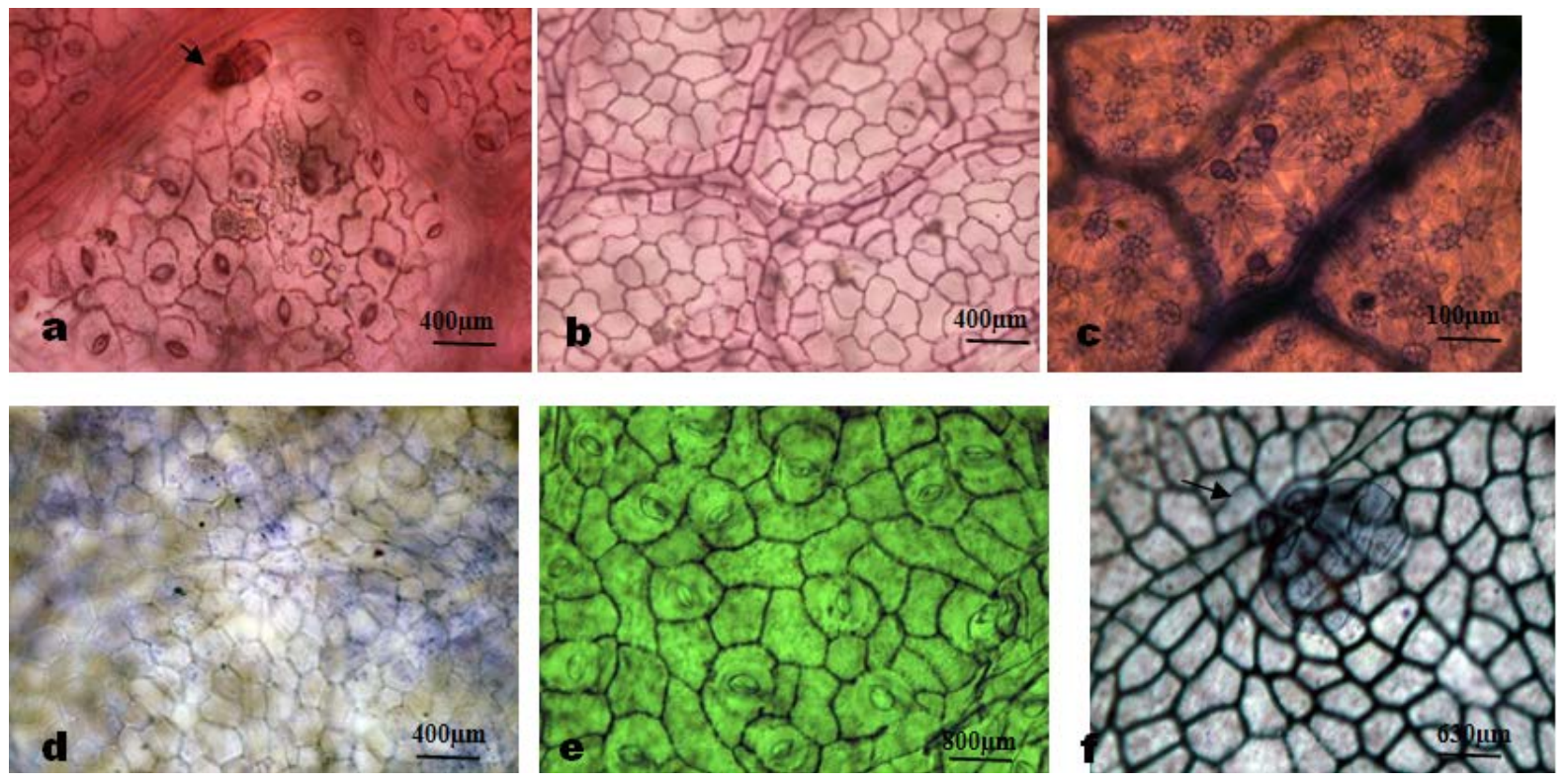

Plate 3. Photomicrographs of leaf epidermal features of Microcos species. (a) M. africana, abaxial surface showing multicellular glandular trichome on the vein and anisocytic, staurocytic and paracytic stomata; (b) Adaxial showing wavy anticlinal cell wall; (c) M. malacocarpa, abaxial surface showing dense distribution of stellate trichome and 2 celled head uniseriate glandular trichomes; (d) Adaxial showing straight anticlinal walls; (e) M. oligoneura, abaxial surface showing anisocytic, staurocytic and paracytic stomata and polygonal epidermal cells; (f) Adaxial showing relatively thick straight to curved anticlinal wall and a cluster of 3 celled head uniseriate glandular trichomes. 
Apart from the small grains, finely reticulate exine sculpture, round to angular or elongated round lumina shape and short colpi length contrast [26] who reported grains with long colpi, perforate and coarse reticulate exine sculpture for the genus Microcos. Reference [31] had reported small pollen grains, short colpi and finely reticulate exine sculpture without bacules for the genus. The round to trilobed Ambient in M. hookerana is characteristic of the species. The Ambient and ora size can be used to separate the genus into two groups correlating with the grouping earlier obtained based on foliar epidermal characters in this study. Pollen data have been used effectively at the generic, subgeneric and sectional levels [32] and [33]. At specific level, pollen can often be helpful in suggesting relationship as observed in the genus Dioscorea Lin. [16]. The uniformity of pollen morphological features observed in this study point to the close inter-relationship among the species in the genus. Nevertheless, the shape of pollen grain is less useful taxonomically because it can vary considerably within one species and the variation may be caused by choice of extracting methods and embedding media [34] and [35].

This work has provided basic information on foliar epidermal and pollen characters which could be employed in the identification of Microcos species in Nigeria. Based on the features observed with the light microscopy, an indented dichotomous key to the species of Microcos in Nigeria is presented.

\section{Key to the Species of Microcos}

1. Pollen ora size $5.4 \mu \mathrm{m}$ to $8.4 \mu \mathrm{m}$; hypostomatic, stomata 70 to 96 ; Amb round or trilobed; glandular trichome 3 to 4 celled..

2. Mean no. of epidermal cells on abaxial surface 189 ; stomata index $27.1 \%$ to $31.2 \%$; pollen subprolate to prolate.

3. Stomata width $13 \mu \mathrm{m}$, stomata index 27.1\%; Amb round, pollen subprolate; adaxial and abaxial cell width 19.8 by $16.0 \mu \mathrm{m}$. Microcos barombiensis

3. Stomata width $16.5 \mu \mathrm{m}$; stomata index 31.2\%; Amb trilobed; pollen prolate; abaxial and adaxial cell width 16.8 by $16.3 \mu \mathrm{m}$. Microcos africana

2. Mean no. of epidermal cells on abaxial surface 196; stomata index 33.6\%; pollen prolate.

.Microcos iodocarpa

1. Pollen ora size $10 \mu \mathrm{m}$ to $12.5 \mu \mathrm{m}$; hypostomatic, stomata 97 to 135; Amb round; glandular trichomes 3 to 5 celled.

4. Adaxial cell wall straight to curve; glandular trichome 3 - 4 celled; pollen subprolate.................5 5. Non glandular trichomes present, abaxial surface densely covered by stellate trichomes; crystal present; stomata index absent. Microcos malacocarpa 5. Non glandular trichomes absent; adaxial surface pilose with glandular and simple trichomes; glandular trichome 3 celled; crystal absent; stomata index $41.4 \%$ Microcos oligoneura

4. Adaxial cell wall undulate; glandular trichomes 4 - 5 celled; pollen prolate........Microcos coriacea

\section{Conclusion}

In conclusion, the foliar epidermal and pollen character of Nigeria Microcos has informative characters for species delimitation and it is useful for identification of morphologically closely related species even at fragmentary state. Further evaluation of the species in the genus for phytochemical properties, anatomical features and phylogenetic study is required to confirm the trend seen here in Nigeria accession. Nevertheless, the present investigation indicates that the foliar epidermal and pollen characters which are apparently significant for species delimitation are epidermal cell shape, cell wall pattern, number of cells in glandular trichomes, shape of the ambient and the pollen ora size. The grouping based on foliar epidermal and pollen characters corresponds with the group based on morphological characters.

\section{References}

[1] Chung, R.C.K. (2003) New Taxa and New Combinations of Microcos (Tiliaceae) from Peninsular Malaysia and Borneo. Kew Bulletin, 58, 329-349. http://dx.doi.org/10.2307/4120619

[2] Chung, R.C.K., Seopadmo, E. and Lim, A.L. (2005) A Synopsis of the Bornean Species of Microcos L. (Tiliaceae). Gardens' Bulletin of Singapore, 57, 101-130.

[3] Bayer, C. and Kubitzki, K. (2003) Malvaceae. In: Kubitzki, K., Ed., The Families and Genera of Vascular Plants, 
Malvales, Capparales and Non-Betalain Caryophyllales, Vol. 5, Springer, Berlin, 225-311.

[4] Chung, R.C.K. (2001) Taxonomic and Micromorphological Studies of Grewia L. and Microcos L. (Tiliaceae) in Peninsular Malaysia and Borneo. Ph.D. Thesis, University of Malaya, Kuala Lumpur.

[5] Chung, R.C.K., Soepadmo, E. and Lim, A.L. (2011) Taxonomic Revision of the Genus Microcos L. (MalvaceaeGrewioideae) in Peninsular Malaysia and Borneo. Blumea, 56, 273-299. http://dx.doi.org/10.3767/000651911X619704

[6] Czarnecka, E., Wiland-Szymanska, J. and Gawronska, K. (2006) Phytogeography of the Genus Microcos L. (Malvaceae, Grewioidae) in Africa. Biodiversity: Research and Conservation, 3-4, 269-271.

[7] Hutchinson, J. and Dalziel, J.M. (1954) Flora of West Tropical Africa. Vol. I, Part 1, 2nd Edition, Crown Agents for Overseas Governments Administrations, London.

[8] Bayer, C., Fay, M.F., De Bruijn, A.Y., Salvolainen, V., Morton, C.M., Kubitzki, K., Alverson, W.S. and Chase, M.W. (1999) Support for an Expanded Family Concept of Malvaceae within a Recircumscribed Order Malvales: A Combined Analysis of Plastid atpB and rbcL DNA Sequences. Botanical Journal of Linnaeus Society, 129, 267-303.

[9] Chung, R.C.K. (2002) Leaf Epidermal Micromorphology of Grewia L. and Microcos L. (Tiliaceae) in Peninsular Malaysia and Borneo. The Gardens’ Bulletin Singapore, 54, 263-286.

[10] Chung, R.C.K., Soepadmo, E. and Lim, A.L. (2003) The Significance of Pollen Morphology in the Taxonomy of Grewia and Microcos (Tiliaceae) in Peninsular Malaysia and Borneo. The Gardens' Bulletin Singapore, 55, $239-256$.

[11] Burret, M. (1926) Beiträge zur kenntnis der Tiliaceae I. Notizblatt des Botanischen Gartens und Museum zu BerlinDahlem, 9, 592-880.

[12] Raju, V.S. and Rao, P.N. (1977) Vanatan in the Structure and Development of Foliar Stomata in the Euphorbiaceae. Botanical Journal of the Linnean Society, 75, 69-97. http://dx.doi.org/10.1111/j.1095-8339.1977.tb01479.x

[13] Stace, C.A. (1965) Cuticular Studies as an Aid to Plant Taxonomy. The Bulletin of the British Museum (National History), 4, 37-40.

[14] Stuessy, T.F. (2009) Plant Taxonomy. The Systematic Evolution of Comparative Data. 2nd Edition, Columbia University Press, New York.

[15] Stace, C.A. (1984) The Taxonomic Importance of the Leaf Surface. In: Heywood, V.H. and Moore, D.M., Eds., Current Concepts in Plant Taxonomy, Academy Press, London, 67-94.

[16] Schols, P., Wilkin, P., Furness, C.A. and Smets, E. (2005) Pollen Evolution in Yams (Dioscorea: Dioscoraceae). Systematic Botany, 30, 750-758. http://dx.doi.org/10.1600/036364405775097743

[17] Ibrahim, J.A., Okhale, S.E., Jegede, A.I. and Kunle, O.F. (2009) The Taxonomy Significance of Agelanthus dodoneifolius (DC.) Polh \& Wiens in Relations to Its Hosts. Nigerian Journal of Botany, 22, 89-101.

[18] Ibrahim, J.A., Makinde, O. and Ibekwe, N.N. (2012) Pharmacognostic, Physicochemical Standardization and Phytochemical Analysis of Leaves of Cultivated Crotalaria lachnosema Stapf. Journal of Applied Pharmaceutical Science, 2, 67-70. http://dx.doi.org/10.7324/JAPS.2012.2914

[19] Dilcher, D.L. (1974) Approach to the Identification of Angiosperms Leaf Remains. Botanical Review, 40, 1-157. http://dx.doi.org/10.1007/BF02860067

[20] Metcalfe, C.R. and Chalk, L. (1979) Anatomy of Dicotyledons. Systematic Anatomy of Leaf and Stem, with a Brief History of the Subject. 2nd Edition, Vol. 1, Clarendon Press, Oxford, 40-41.

[21] Salisbury, E.J. (1927) On Cause and Ecological Significance of Stomata Frequency with Special Reference to Woodland Flora. Philosophical Transactions of the Royal Society of London, Series B, 216, 1-65.

[22] Erdtman, G. (1952) Pollen Morphology and Plant Taxonomy. Chronica Botanica, Co., Waltham, 539 p.

[23] Erdtman, G. (1960) The Acetolysis Method—A Revised Description. Svensk Botanisk Tidskrift, 54, 561-564.

[24] Ayodele, A.E. (2005) The Morphology and Taxonomic Significance of Pollen in the West-African Polygonaceae. Thaiszia Journal of Botany, 15, 147-149.

[25] El-Husseini, N. (2006) Pollen Morphology of Tiliaceae and Sterculiaceae and Their Relations to Malvaceae in Egypt. International Journal of Agriculture and Biology, 8, 844-847.

[26] Perveen, A., Grafstrom, E. and El-Ghazaly, G. (2004) World Pollen and Spore Flora 23. Malvaceae, Subfamilies: Grewioideae, Tilioideae, Brownlowioideae. Grana, 43, 129-155. http://dx.doi.org/10.1080/00173130410000730

[27] Solereder, H. (1908) Systematic Anatomy of the Dicotyledons: A Handbook for Laboratories of Pure and Applied Botany. Vol. 2, Clarendon Press, Scott, Oxford.

[28] Goldschmidst, E.E. (1996) Biology of Citrus. Cambridge University Press, Cambridge.

[29] Metcalfe, C.R. and Chalk, L. (1983) Anatomy of the Dicotyledons. Vol. 2, The Clarendon Press, Oxford.

[30] Sheteolu, A.O. and Ayodele, A.E. (1997) Epidermal Morphology of the Genus Dialium (Fabaceae: Caesalpinoideae). 
Feddes Repertorium, 108, 151-158.

[31] Sowunmi, M.A. (1973) Pollen Grains of Nigerian Plants. Grana, 13, 145-186. http://dx.doi.org/10.1080/00173137309429891

[32] Bigazzi, M. and Slevi, F. (1998) Pollen Morphology in the Boragineae (Boraginaceae) in Relation to the Taxonomy of the Tribe. Plant Systematics and Evolution, 213, 121-151. http://dx.doi.org/10.1007/BF00988912

[33] Vezey, E.L., Watson, L.E., Skvarla, J.J. and Estes, J.R. (1994) Plesiomorphic and Apomorphic Pollen Structure Characteristics of Anthemideae (Asteroideae: Asteraceae). American Journal of Botany, 81, 648-657. http://dx.doi.org/10.2307/2445741

[34] David, P.H. and Heywood, V.H. (1963) Principle of Angiosperms Taxonomy. Van Nostrand, Princeton.

[35] Moore, P.D., Webb, J.A. and Collinson, M. (1991) Pollen Analysis. Blackwell, London, 226 p. 
Scientific Research Publishing (SCIRP) is one of the largest Open Access journal publishers. It is currently publishing more than 200 open access, online, peer-reviewed journals covering a wide range of academic disciplines. SCIRP serves the worldwide academic communities and contributes to the progress and application of science with its publication.

Other selected journals from SCIRP are listed as below. Submit your manuscript to us via either submit@scirp.org or Online Submission Portal.
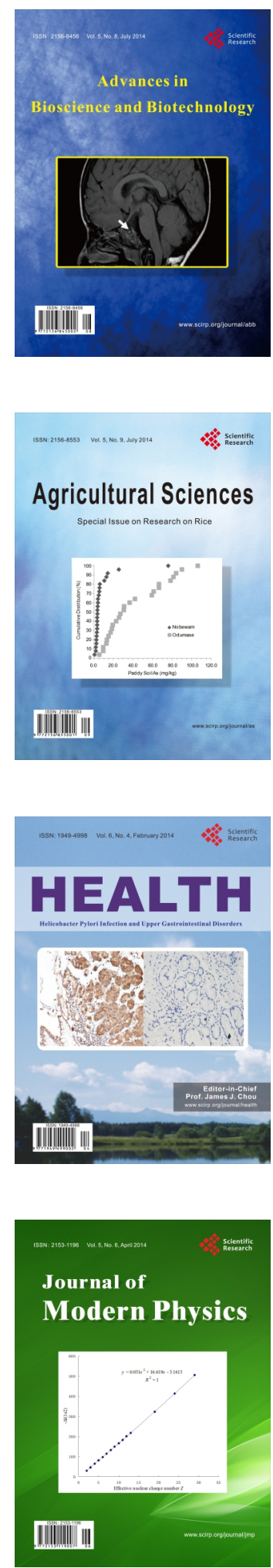
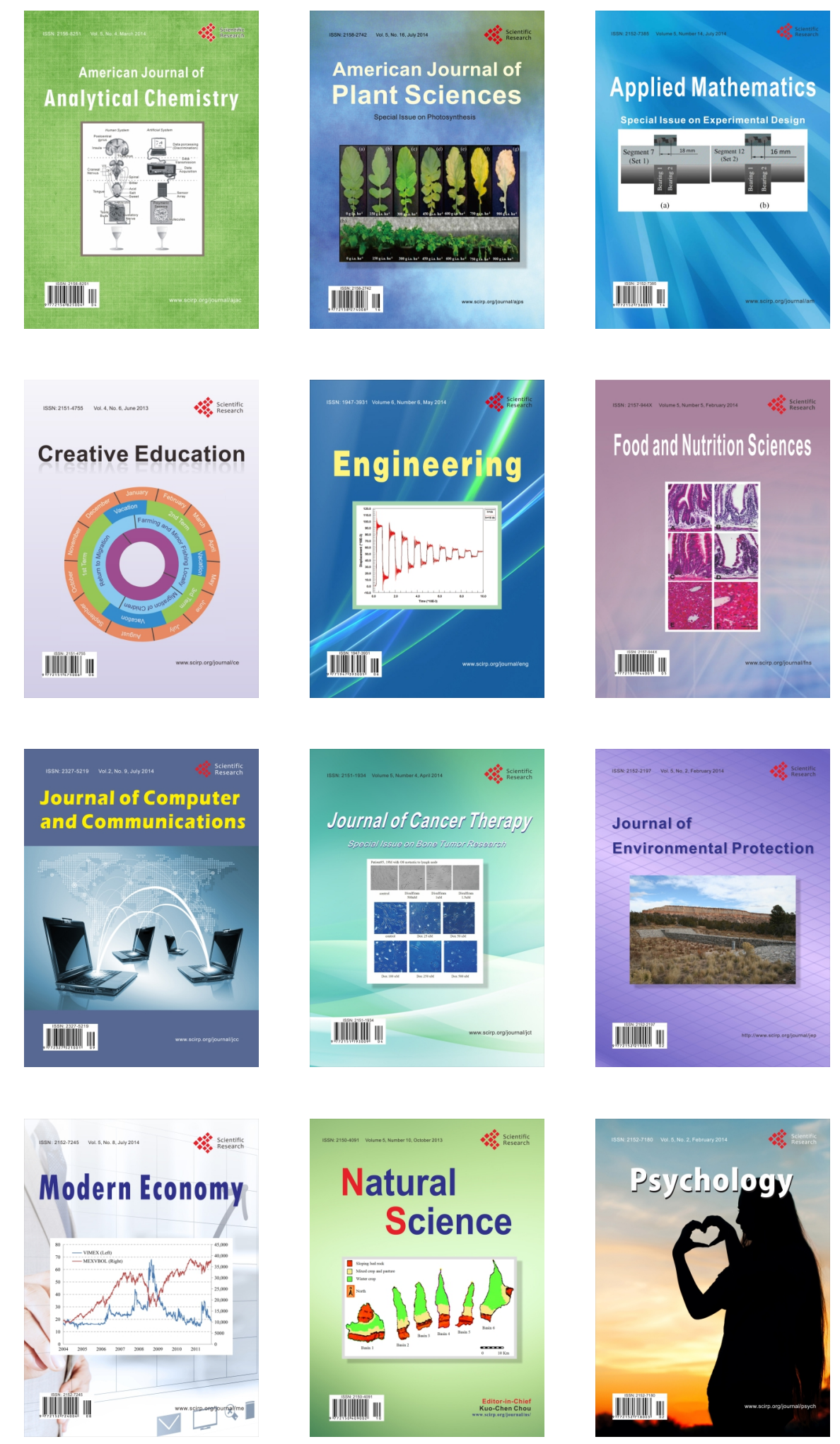